\title{
Impact of Audit Committee Attributes on Financial Reporting Quality of Deposit Money Banks in Nigeria
}

\author{
Gehya Emmanuel Filli \\ Department of Accountancy Federal Polytechnic Mubi, Adamawa State Nigeria
}

\begin{abstract}
The audit committee is one of the corporate governance mechanisms vested with the responsibility of monitoring the financial reporting process of corporations. This paper examines the impact of audit committee attributes of expertize, meeting frequency, independence, attendance and size on financial reporting quality of deposit money banks in Nigeria. Top ten banks based on asset capitalization were sampled during the period 2008-2017. Data was extracted from their annual report and analysed using pooled OLS regression and the Fixed effect test. Firm age and firm size were introduced as control variables in the regression model. The result of the analysis shows that audit committee attributes of attendance and independence has negative and statistically insignificant impact on financial reporting quality of deposit money banks in Nigeria while audit committee attributes of size and meeting frequency has positive and statistically insignificant influence on financial reporting quality. However only audit committee attribute of expertise seems to be positive and statistically significant at influencing financial reporting quality of deposit money banks in Nigeria. Firm age and size were also found to be positive and statistically significant at influencing financial reporting quality of deposit money banks in Nigeria. The paper recommends among others that regulatory bodies like the Financial Reporting Council of Nigeria (FRCN) and the Central bank of Nigeria being the apex bank should make it a policy for banks to ensure that appointment of members of the audit committee is based on expertise that is, members of the committee must possess relevant knowledge in accounting and belong to a professional body of accounting.

Keywords: Audit committee, Expertise, Attendance, Meeting frequency, Independence, Size, Financial Reporting Quality.
\end{abstract}

DOI: $10.7176 /$ RJFA/10-4-04

\section{INTRODUCTION}

Financial reporting which is usually considered as the end product of accounting is the disclosure of financial information to various stakeholders about the financial position and performance of a corporate entity during an accounting period. The primary objective of financial reporting is to provide information about the financial position, performance and changes in financial position of a corporate entity (IASB,2008). These stakeholders include investors, shareholders, government agencies (tax authorities), and creditors. These users are not only limited to the aforementioned but also include the management of the entities who use this report for planning, analysis and decision making. In attaining these objectives as outlined by the IASB(2008) high quality report is important because financial report is the means through which the various users assess the wellbeing of a corporate entity.

The demand for quality financial report round the globe arose due to failure of some corporations such as Worldcom, Enron, African Petroleum, Spring bank and Highland bank which made users of such report to lose confidence hence demand for quality report. These brought about reforms in some countries such as the Cadbury Report in UK, Sabanes Oxley Act (2002) in the US, the South African Dey report(1994) in South Africa, the Nigerian Code of Corporate governance (2003) and the German Corporate Governance Code in Germany. These regulations were meant to improve the quality of financial report and curb corporate failure thereby increasing the confidence of users in the report.

The Financial Accounting Standard Board (FASB,1999) and the International Accounting Standard Board (IASB,2008) emphasized that a quality financial report is one that is characterised by its relevance, faithful representation, understandability, comparability, verifiability and timeliness. Ferdy, Geert and Suzanne, (2009) views financial reporting quality from two perspectives that is, fundamental and enhancing qualitative characteristics. The fundamental qualitative characteristics are relevance and faithful representation which are classified as the most important in determining the content of a financial report whereas the enhancing qualitative characteristics are those characteristics that improve decision usefulness when the fundamental qualitative characteristics are established and include understandability, comparability, verifiability and timeliness.

In an attempt to improve financial reporting quality various legislation enacted and reforms introduced emphasized the need for establishment of audit committee. Audit committee is a committee made up of members of the board of directors who play the role of consolidation of financial control within a company (Yousof, 2010). The committee is vested with the responsibility of monitoring the financial reporting process, monitoring the effectiveness of the internal control system or internal audit, risk management, monitoring the independence of the statutory auditor and provisions of additional services, among others (Andrie \& Melinda, 2014). In the same 
vein, Yuanto, Kwong, Themin \& Jiwei (2015) attest that the audit committee's primary objective is supervision of the financial reporting process to ensure managers reports their corporation's performance ethically.

From the functions of the audit committee as earlier stated, the committee is seen as one of the important mechanism for ensuring quality financial reporting by corporate entities. However, the effectiveness of audit committee in ensuring quality financial report is dependent on its attributes. These attributes are the inherent features which the committee must possess in order to effectively discharge its responsibilities. The attributes that affect the effectiveness of the audit committee include Size, Financial expertise, Meeting frequency, Independence and Attendance at meetings (Yousof, 2010). It has been argued that establishment of audit committee in its financial reporting process will not necessarily guarantee financial reporting quality unless, the committee possess the right attributes. Mcmullen \& Raghunandan (1996) affirmed that the success of the audit committee in promoting financial report quality is dependent on the audit committees attributes. The more independent, more capable, and more qualified members of the audit committee are, the better the skill to detect material misstatement in the financial information and dissuade any advancement by the management to manipulate financial report (Siriyana \&Norah, 2017).

Several studies have been done on audit committee attributes and financial reporting quality for instance, the works of Yuanto et al., (2015) was based on three attributes viz independence, expertize and overlapping membership and their impact on financial reporting quality for Singapore listed companies using cross-sectional regression model to test data collected. Their result/analysis revealed that financial reporting quality will be higher if the committee is comprised of mixed expertize in accounting, finance and supervision and that independence of the committee members is certain since the committee comprise of independent directors. Similarly, Ormin \& Tuta (2004) also studied audit committee attributes of independence, meeting frequency and attendance and financial reporting quality of listed Nigerian deposit money banks using Descriptive statistics, Pearson correlation statistics and Ordinary Least Square Regression to analyse data. The result of their analysis shows that the committee's independence and attendance at meeting has negative and insignificant influence on financial reporting quality whereas meeting frequency and the control variable of firm size and age has positive and significant influence on financial reporting quality. However this paper intends to go further by studying all the audit committee's attributes that is, size, expertise, meeting frequency, attendance and independence. It is against this backdrop that this paper examines the impact of audit committee attributes on financial reporting quality of deposit money banks in Nigeria. Specifically, the paper tests the following hypothesis:

$\mathrm{Ho}_{1}$ : Audit committee size has no significant influence on financial reporting quality of deposit money banks in Nigeria.

$\mathrm{Ho}_{2}$ : The expertise of members of the audit committee has no significant influence on financial reporting quality of deposit money banks in Nigeria.

$\mathrm{Ho}_{3}$ : Frequency of audit committee meeting has no significant influence on financial reporting quality of deposit money banks in Nigeria.

$\mathrm{Ho}_{4}$ : The independence of the audit committee has no significant influence on financial reporting quality of deposit money banks in Nigeria.

Ho5: Audit committee attendance has no significant influence on financial reporting quality of deposit money banks in Nigeria.

The paper provides insight into the impact of audit committee attributes in promoting financial reporting quality. It will therefore be valuable to stakeholders who may wish to understand the extent to which audit committee attributes influences positively financial reporting quality. The paper is structured into five sections. Following the introduction, section two covers literature review, section three methodology, section four analysis and discussion; section five conclusion and recommendation.

\section{Literature Review}

\section{Conceptual Clarification: Audit Committee}

Robinson \& Owen (2009) define audit committee as selected members of a company who are vested with the sole responsibility of overseeing the company's accounting and financial reporting policies and practices. The audit committee is one of the major operating committees of a company board of directors that is in charge of overseeing financial reporting and disclosure. According to Menon \& William (1996) the audit committee can be described as a sub-committee of the board of directors that shoulder some of the responsibilities of the board of directors particularly to oversee the company's financial reporting process. In order to enhance the integrity of financial report, audit committee is seen as one of the obligatory committee of the board of directors as stated by CAMA,( 2004) that promote good corporate governance thereby providing support to the board.

In Nigeria, the origin of audit committee can be traced back to section 359(3) of the Companies and Allied Matters Act (CAMA) where the Act provides for the establishment of audit committee in public companies. The Act documented that each public company shall constitute an audit committee which shall be made up of equal number of directors and shareholder. Furthermore, the Act states that the number of the committee shall not exceed 
six. The creation of audit committee in Nigeria was further strengthen to increase financial reporting quality following the establishment of the Corporate Governance Code of Best Practice issued by the Securities and Exchange Commission (SEC) in 2003. Similarly, other nations round the globe has also established audit committee in order to strengthen the quality of financial report such as the New York Stock Exchange (1939), the Canadian Legislative Council (1978) and the Sabanes Oxley Act (2002). This shows that the audit committee serve as a liaison between the company's board of directors, the external and internal auditors in ensuring that a company's financial statement show a true and fair view of the state of affairs of the company.

This audit committee possess some characteristics/attributes which must be adhered to in order to discharge their responsibilities effectively. These attributes include audit committee size, expertize, frequency of meetings, independence and attendance (Yousof, 2010). The size is concerned with the number of persons that make up the committee, expertise is concerned with ensuring that members of the committee are expert in accounting and financial related matters, members of the committee must be independent of management, with regard to frequency of meetings, CAMA 2004 as amended stipulates that the audit committee meet at least three times in a year. Independence refers to members of the committee not receiving any compensation from the company except in respect of its membership as an audit committee (SOX Act, 2002). These attributes sharpen the process of accountability of the audit committee and increases financial reporting quality.

\section{Financial Reporting Quality}

Financial reporting is the disclosure of financial information to management and the public about how a company is performing over a specific period of time (Shawn, 2003). It is seen as a means of communicating financial information to users of such information. It is often regarded as the end product of accounting as it assist users of such information in measuring and monitoring economic performance of a business entity to enable economic decisions (Warren \& Reeve, 2004). Therefore, the demand for financial reporting quality by these users became on the increase and has received a lot of debate among financial regulators, investors and professionals (Xiaosong, 2010).

Financial reporting quality has been defined in different ways due to difference in reporting environment, legislation and regulators. However, Omin \& Tuta (2014) opined that the different views are characterised by the unit of precision, relevance, actuality and usefulness of the report. The Austriala's Accounting standard Board (AASB), the Accounting Standard Board in United Kingdom (ASB) and the International Accounting Standard Board (IASB) assert that financial reporting quality represent financial statements that offer precise and rational information about the financial status and economic wellbeing of an entity. In the same vein, the FASB, (1999) define financial reporting quality as accuracy of information presented in a financial statement more specifically the cash flow statement which enable equity investors determine the viability of future strategic decisions they make.

The cash flow statement is a statement that contains information on how much cash a company has generated and used during a given period. The cash flow statement is characterised by operating activities, investment activities and financing activities. Basically, the financial statement or financial report is characterised by three basic element that is, the balance sheet which shows the firm's asset, liabilities and net worth on a stated date; income statement also called profit and loss account which shows the net income of a firm over a stated period and the cash flow statement which shows the inflows and outflows of cash over a stated period. Equity investors are particularly more interested in the cash flow statement which makes the cash flow statement an essential element of a financial report. Since cash flows are recorded based on accrual basis of accounting, the accrual quality is of utmost importance. Accrual quality is a substantial model that has been used to measure the quality of financial reporting (Sirijana and Nora, 2017). This supports the works of Gary et al (2009) that use accrual quality as a proxy for financial reporting quality and that accruals improve the informativeness of earnings by ironing out transitory fluctuations in cash flows. However, the works of Ferdy et al (2009), reported that the quality of financial reporting information based on accrual models do not provide direct and comprehensive evidence concerning the quality of financial report since it is an indirect proxy of earnings quality excluding nonfinancial information and recommends that a complete measurement tool of financial reporting quality would include both financial and nonfinancial information. This approach is considered more applicable owing to the fact that it captures a complete annual report which comprises of financial and nonfinancial information. This approach is considered more significant owing to the fact that it captures a complete annual report which comprise of financial and non- financial information like the balance sheet and income statement are included in measuring financial reporting quality.

\section{Characteristics of financial reporting quality}

Financial reporting quality is characterised by certain features that are use in determining financial reporting quality as proposed by the FASB, 2008). These qualities include faithful representation, understandability, comparability, verifiability and faithfulness. The emphasis is on having a qualitative financial report to users. 
These qualitative characteristics of financial reporting quality are divided into fundamental qualitative characteristics and enhancing qualitative characteristics. According to Ferdy et al (2009), the fundamental qualitative characteristics are those that are classified as the most important in determining the content of financial reporting information which include relevance and faithful representation while the enhancing qualitative characteristics are those characteristics that improve decision usefulness when the fundamental qualitative characteristics are established. These enhancing qualitative characteristics include understandability, comparability, verifiability and timeliness. A theoretical explanation of these qualitative characteristics is given below:

Relevance: A financial report is said to be relevant when it influences users of such report to assess the report and make justifiable economic decisions based on the past, present and future forecast of event. According to IASB (2008), as documented in Ferdy et al (2009), relevance is the aptitude of making a difference in the decisions made by users in their capacity as capital providers. Siriyana and Norah (2017) posit that relevance is closely associated with usefulness and materiality. That information that helps to evaluate current and past event is said to be useful when it attain the principle of materiality.

Faithful representation: A faithful representation is a representation that is free from bias and material misstatement. Annual reports are expected to be presented faithfully. However, Ferdy et al (2009) opined that an annual report can never be completely free from bias since economic occurrences presented in annual report are often measured under conditions of uncertainty yet, it is of utmost importance for a financial report attain certain degree of accuracy in order to be decision useful (IASB, 2008).

Understandability: Understandability is concerned with effective information. An information is said to be effective when users of such information comprehends and make meaningful economic decision from it. Thus, the better the understanding of information by users, the better the chances of a report classified as a quality report. Beest, Braam \& Boelens (2009) assert that a well-organized annual report make users comprehends what their needs are. Moreover, the Institute of Chartered Accountant of New Zealand (ICANZ, 1993) opines understandability as the aptitude by which users of financial information read and comprehend information in a financial report.

Timeliness: The IASB (2008) views timeliness as the time it takes to make financial information available to users. According to Beest et al (2009), timeliness is use in assessing the quality of a financial report by using the period between the year end and the issuing date of the auditor's report at the end of the financial year.

Comparability: comparability is the ability of users to compare financial statement with previous years in order to determine the financial position and performance of an entity (Siryana and Norah, 2017).

Verifiability: The IASB (2008) posits that verifiability is concerned with the assertion that information presented in a financial report actually present the economic situation to its users.

\section{Audit Committee Attributes and Financial Reporting Quality}

Attribute of size and Financial Reporting Quality: The attributes of size is concerned with the number of persons that make up the committee. Thus, CAMA (2004) as amended posits that the audit committee shall consist of an equal number of directors and representatives of the company's shareholders subject to a maximum number of six members. However, the United State of America and United Kingdom recommends a maximum of three (3) members to serve as audit committee (Andrie \& Melinda, 2014). Bertschinger \& Schaad (2003) are of the view that the number of audit committee should not be more than four persons going by the above it could be deduced that the size of the committee ranges from three to six persons and that firm size is a determinant factor in influencing audit committee size. Samuel, Mudzamir \& Mohammed (2017) affirm that the size of the committee depends on firm size and other related factors as bigger firms operates in bigger financial reporting quality. The works of Belkaoni (2000); Deli \& Gillan (2000); Piot (2000); Barako (2006) and Arrondo-Garcia (2000) shows that the demand for audit committee increases with firm size. Falko \& Laury (2016) added that audit committee audit committee size might also depend on the type of industry in which the firm operate as the demand for audit committee seems to be high among financial institutions. Moreover, most empirical studies support the perception that audit committee size influences financial reporting quality as there are more prospects for companies that grow in size to operate in bigger financial reporting quality. Therefore, firm size serve as a yardstick for measuring audit committee size in ensuring financial reporting quality.

Expertise of Members of Audit Committee and Financial Reporting Quality: Expertise is concerned with financial knowledge and experience of members of the audit committee. Since the main objective of audit committee is to supervise financial reporting process of a company. It is assumed that members of such committee must be financial expert in order to produce high quality financial report (Yuanto et al., 2015). Moreover, the US Sarbanes Oxley Act of 2002, the UK Corporate Governance Code (2010); Corporate Governance Principles and Recommendation issued by the Australian Securities and Exchange Commission all recommends that at least one person from the committee must possess recent and relevant financial experience. Likewise, the Singapore Code of Corporate Governance issued by the monetary authority of Singapore recommends public firms in Singapore 
have at least two of the members of the audit committee including the committee's chairman to possess recent and relevant accounting knowledge.

If the main objective of audit committee is to provide adequate scrutiny on a company's accounting and financial reporting quality, there is no doubt that such fundamental requirement of the audit committee is proved to be essential in dealing with complex financial report in order to achieve a qualitative report (Dezort \& Saltterio, 2001). Yuanto et al (2015) also attested to the fact that financial expertise of members of the audit committee have more effective means to monitor management financial reporting policies so as to yield higher quality financial report. Financial expertise could mean members possessing relevant accounting or related financial management experience and/or belonging to a recognised accounting professional body though the definition of financial expert varies from country's code to code (Yuanto et al., 2015). Joseph, Carl, April and Terry (2006) are of the view that firms could designate a financial expert to include directors from a larger cadre including top managers from other companies, investment bankers, venture capitalist and others which include accounting and non- accounting financial expertise, as audit committee can benefit from a mix of accounting and non-accounting expertise from finance and management (Hillman, Cannella \& Paetzort, 2000; and Cohen, krishnamorthy \& Wright 2008).

Frequency of Audit Committee Meeting and Financial Reporting Quality: frequency refers to the number of times the audit committee meet in order to consider and discharge their responsibilities accordingly. How frequent these committee members meet shows how diligent and active they are considering the capacity of work at hand. According to the Treadway Commission (1987), an active audit committee must meet regularly in order to execute its duties and responsibilities which among others include enhancement of financial reporting quality. Robinson and Owen-Jackson (2009) are of the view that diligent audit committee meet regularly which shows greater commitment are more likely to be effective observers and therefore can reduce the frequency of financial reporting difficulties (Erena \& Tehulu, 2012).

The audit committee's activity cannot actually be measured in quantitative terms however, Dezort, Hermanson, Archambeault \& Reed, (2002) assert that the number of audit committee meetings per annum is a substitute for measuring the committee's diligence. Similarly, Omin \& Tuta (2004) are also of the view that the quantum of work of the committee in monitoring management activities is not about number of hours spend at a particular sitting but the number of meeting held in a year. CAMA (2004) recommends that the audit committee meet at least three times in a year however, the size of a firm in most cases influences the number of meetings as larger firms meet more often even beyond four times in a year as the need arise in order to make positive impact on financial report. Al-Baidhani (2014) argues that the frequency and duration of these meetings have to be according to firm size and issues discussed during such meetings as four times a year could be too much for some firm while twelve times a year could just be sufficient for others. Audit committee that holds a minimum of four meeting in a year is likely to reduce the incidence of financial mis-statement thereby producing a high quality report (Abbott, Parker \& Peter 2004).

Audit Committee's Attendance at Meeting and Financial Reporting Quality: Attendance is concerned with the number of times each member of the audit committee attends meetings and participate in deliberations in order to achieve the committee's objective. It demonstrate diligence which is seen as the enthusiasm of audit committee members to pursue their goals (Samuel et al., 2015). Moreover one of the main duties of the committee is to ensure a quality financial report by firms which implies that the higher the attendance of members at meetings the more likely hold of the committee to be effective; the better the quality of financial reporting (Omin \& Tuta 2014)

Audit Committee Independence and Financial Reporting Quality: The SOX Act, (2002) refers independence of the audit committee to members not receiving any compensation from the company except in respect of membership as an audit committee. However, independence is being able to discharge ones responsibilities without any interference from within or outside. Although the requirement for independence vary from one country code to another, the Blue Ribbon Committee (1999) among its recommendations for audit committee recommends that members of the committee must be independent of the company and not part of management and knowledgeable in the field of accounting. The audit committee are expected to play the role of a liaison officer between management and the external auditors therefore independence is of utmost importance since the two parties may have difference in appropriate opinion on how to best apply accounting standards (Klein, 2002). Omin \& Tuta (2014) assert that the audit committee is better able to promote financial reporting quality when the committee is free from any interference from those upon whose duty it performs an oversight function, independence of the committee members will also be of assistance to help balance conflicting views of external auditors and management to yield a high quality financial report (Yuanto et al., 2015)

\section{Methodology}

This paper examines the impact of audit committee attributes on financial reporting quality of selected Deposit Money banks (DMBs) in Nigeria for the period 2008 -2017. The period 2008 -2017 was taken so as to be able to capture the post-audit reforms issued by the Central bank of Nigeria in the year (2002) on code of corporate governance specifically for banks. The study investigated the impact of audit committee attributes in a panel 
framework for the ten (10) selected DMBs in Nigeria. The DMBs that have been selected for the purpose of the study are; Access Bank Pls, First Bank Plc, Guarantee Trust Bank Plc, Ecobank Bank Plc, United Bank for Africa Plc, Union Bank plc, Diamond Bank Plc, Zenith Bank Plc, and Fidelity Bank Plc, and Skye (Polaris) Bank Plc. The banks were selected based on asset ranking of which the top ten banks in terms of asset worth were selected and sampled. Data was generated from the annual reports and account of the sampled banks. The independent variables are audit committee attribute of size, expertise, meeting frequency, independence and attendance while the dependent variable is financial reporting quality. Firm size and age were introduced as control variables.

The model for the study was adopted from Ormin \& Tuta (2014) with modifications. The model adopted from Omin \& Tuta (2014) modelled financial reporting quality (FRQ) as a dependent variable, against independent variables like Audit committee independence (ACIND), Audit committee frequency of meetings (ACFREQ), Audit committee meeting attendance (ACATT), Firm age (FAGE) and Firm size (FSIZE). The model was expressed as;

$$
F R Q_{i t}=\beta_{0}+\beta_{1} A C I N D_{i t}+\beta_{2} A C F R E Q_{i t}+\beta_{3} A C A T T_{i t}+\beta_{4} F A G E_{i t}+\beta_{5} F_{S I Z E_{i t}}+\mu_{i t}
$$

Thus, the modified model is expressed as:

$$
F R Q_{i t}=\beta_{0}+\beta_{1} A C I_{i t}+\beta_{2} A C E_{i t}+\beta_{3} M F_{i t}+\beta_{4} A C A_{i t}+\beta_{5} A C S_{i t}+\beta_{6} F R S_{i t}+\beta_{7} F R A_{i t}+\mu_{i t}
$$

Where;

$\mathrm{FRQ}_{\mathrm{it}}=$ Financial reporting Quality

$\mathrm{ACI}_{\mathrm{it}}=\quad$ Audit Committee Independence

$\mathrm{ACE}_{\mathrm{it}}=$ Audit Committee Expertise

$\mathrm{MF}_{\mathrm{it}}=\quad$ Meeting Frequency

$\mathrm{ACA}_{\mathrm{it}}=$ Attendance in Meetings

$\mathrm{ACS}_{\mathrm{it}}=$ Audit Committee Size

$\mathrm{FRS}_{\mathrm{it}}=\quad$ Firm size (proxied by firm's assets in millions)

$\mathrm{FRA}_{\mathrm{it}}=$ Firm age in years

The dependent variable, financial reporting quality (FRQ) is subjective, and it took any value on a scale of 110 , with 10 being very good financial reporting quality and 1 being very poor financial reporting quality. Even though the rating was subject to the discretion of the author, it was dependent on some factors like number of expertise among members of audit committee and firm age.

The independent variables used in the model such as ACE which is obtained by the ratio of audit committee membership with relevant financial experience and a member of relevant financial professional body (SOX Act, 2002). The audit committee independence ACI is a function of the ratio of committee members that are independent non-executive directors to those who are not (Andrie \& Melinda, 2014). This is because an audit committee member who is equally a director in a firm is assumed not to be independent of the firm. Other independent variables used are frequency of meetings (MF) which is measured as the number of meetings held by the committee in a year (Andrie \& Melinda, 2014), audit committee size (ACS) is measured as the number of persons that make up the committee of which firm size is a factor in determining audit committee size (Samuel et al., 2017). Audit committee attendance in meetings (ACA) is measured as the ratio of attendance by members to the total number of meetings held in a year while firm age (FRA) and firm size (FRS) serve as the controlled variables.

The data were analysed using the pooled Ordinary Least Square (OLS) which is a panel data estimated using OLS estimation technique, based on the assumption that the model has the same trend and intercept and that there are no firm-specific effects in the data. Random and fixed effect models were also used to estimate the relationship and the Hausman test was used to choose the most efficient result between the random effect and fixed effect, based on the result and probability of the Hausman test. 


\section{Results and Discussion}

\begin{tabular}{|l|l|l|l|}
\hline & Pooled OLS & Random Effects & Fixed Effects \\
\hline Constant & $-0.377109(0.1217)$ & $-0.309899(0.0660)^{* *}$ & $-0.165426(0.3999)$ \\
\hline Ln ACA & $0.07745(0.5315)$ & $-0.0266(0.7395)$ & $-0.068421(0.4221)$ \\
\hline Ln ACE & $0.306425(0.000)^{*}$ & $0.317803(0.000)^{*}$ & $0.0321504(0.000)^{*}$ \\
\hline Ln MF & $-0.095909(0.6444)$ & $-0.012814(0.9259)$ & $0.016573(0.9096)$ \\
\hline Ln ACI & $-0.134491(0.0815)^{* *}$ & $-0.105623(0.0578)^{* *}$ & $-0.074545(0.2098)$ \\
\hline Ln ACS & $-0.362561(0.4407)$ & $0.091620(0.7601)$ & $0.233860(0.4437)$ \\
\hline Ln FRS & $0.0086(0.9192)$ & $0.059831(0.3146)$ & $0.072824(0.2543)$ \\
\hline Hausman Test & $0.3369(0.0000)^{*}$ & $0.236388(0.0215)^{*}$ & $0.010077(0.9682)$ \\
\hline
\end{tabular}

Source: author's computation using E-views 8, 2018.

Probability values in parenthesis

* Significant at $5 \%$ level of significance

** Significant at $10 \%$ level of significance

Based on the results presented in the table above, the results of the Pooled OLS, the random effects and the fixed effects model are presented. The result of the pooled OLS suggests that financial reporting quality (FRQ) is positively related to firm size and firm age, audit committee expertise and attendance in meetings. However, it is negatively related to meeting frequency, audit committee independence and audit committee size. Firm age was found to be positive and statistically significant impact on financial reporting quality. Firm size has a positive but statistically insignificant impact on financial reporting quality. Audit committee independence is found to have negative and statistically significant impact on financial reporting quality at $10 \%$ level of significance. However, Audit Committee Expertise (ACE) was found to have a positive and statistically significant impact on financial reporting quality (FRQ). The coefficient of ACE being 0.306425 suggests that if audit committee expertise will increase by 1 unit, financial reporting quality FRQ will increase by 0.306425 units. The coefficient of ACA being 0.07745 suggests that if ACA should increase by 1 unit, FRQ will increase by 0.07745 units. The coefficient of FRS and FRA being 0.0086 and 0.3369 respectively suggests that if FRS and FRA should increase by 1 unit, FRQ will increase by 0.0086 and 0.3369 units respectively. The coefficient of audit committee size (ACS), being 0.362561 suggests that if ACS should increase by 1 unit, FRQ will decrease by 0.3625 units. The coefficient of meeting frequency (MF) being -0.095909 suggests that if meeting frequency should increase by 1 unit, FRQ will decrease by 0.095 units. ACI has a coefficient of -0.134491 which suggests that if ACI should increase by 1 unit, FRQ will decrease by 0.134491 units.

The random effects and fixed effects models are also estimated. The result of the Hausman test is a pointer to whether the random effects model results is more efficient or the fixed effects result is more efficient. The null hypothesis of the Hausman test which states that the random effect model is more efficient than the fixed effect model normally favours the random effects result, however, since the probability of the statistic is 0.0027 , which is less than 5\%, the null hypothesis is rejected. Therefore, the results of the fixed effects model is more efficient than the random effects result. In conclusion, the result of the fixed effects model will be interpreted.

Fixed Effects Result

The result of the fixed effect model suggest that audit committee expertise, meeting frequency, Audit Committee size, firm size and age all have positive impacts on Financial Reporting quality, however, Audit Committee Attendance (ACA) and Audit Committee Independence (ACI) have negative impacts on Financial Reporting quality.

The coefficient of Audit Committee Expertise being 0.0321504 suggest that ACE should increase by 1 unit, FRQ will equally increase by 0.0321504 units, and this variable will equally be significant in explaining FRQ. The fixed effect result and pooled OLS shows that audit committee expertise has positive and statistically significant influence on financial reporting quality of deposit money banks in Nigeria at 5\% level of significance therefore the null hypothesis is rejected. This finding is consistent with prior studies by Cacello \& Neal (2003), Joseph, Carl \& April (2006) and Samuel (2012) who found that audit committee expertise influences financial reporting quality. Literally, a contemporary meaning of expert in this context refers to financial expert and experience which include both accounting and non-accounting knowledge. These includes an understanding of audit related matters and judgement, risk, internal control and variations between management and external auditors (Samuel et al., 2017) The Nigerian code of corporate governance code require at least a member of the audit committee must be a financial expert which equally applies to deposit money banks. This shows that the absence of an expert among members of the audit committee can jeopardize the integrity of a financial report. Carcello \& Neal (2003) argued that such requirement of audit committee expertise is fundamental in dealing with the complexities of financial reporting and also serve as a means of increasing financial reporting quality.

Meeting Frequency (MF) with a coefficient of 0.016573 has a positive not statistically significant impact on 
FRQ. Its coefficient of 0.016573 suggest that if MF should increase by 1 unit, FRQ will increase by 0.016573 units. Though the positive relationship between audit committee meeting frequency and financial reporting quality does not conform to expectation of which the null hypothesis will be rejected, there are several evidence to confirm that there is evidence to conclude that the audit committee attribute of meeting frequency has influence of financial reporting quality. For proper performance and adequate positive result, regular meetings by members of the committee is a necessity (Andrie \& Melinda, 2014). The frequency of such meetings is not merely based on number of times held and hours spend but mostly the committee's diligence in reviewing the financial activities of the management. Diligence is concerned with a combination of carefulness and long term effort by the committee. Samuel et al, (2017) assert that audit committee diligence is the eagerness of the committee in pursuing its objectives. Therefore, audit committee that meet frequently demonstrate greater commitment and are more likely to ensure a high quality report. This is in line with the Treadway Commission (1987) which states that regular meetings of the audit committee play a significant role in enhancing financial reporting quality.

The coefficient of ACI being - 0.074545 suggest that if Audit Committee Independence should increase by 1 unit, FRQ will decrease by 0.074545 units. However, ACI is not statistically significant in influencing FRQ therefor the null hypothesis is accepted. The result of this study is consistent to the findings of Yuanto et al (2015) who equally found out that Audit Committee Independence (ACI) has a negative and statistically insignificant impact on financial reporting quality (FRQ). It is however, inconsistent with the findings of Moau (2003), Klein (2002), and Vafeas (2005) who found that there is a relationship between audit committee independence and financial reporting with control over earnings management that is, a positive impact of audit committee independence on financial reporting quality (FRQ). This shows that the audit committee effectiveness lies on its independence in discharging its responsibilities. Attainment of this independence could also be attributed to the combination of the committee members that is, the number of inside and outside directors involved. Klein (2003) noted that the independence of the audit committee is mostly affected by the ratio of outside directors to inside directors. Where majority of the committee are outside directors, it will be difficult to manipulate financial report thereby leading to high quality financial report.

The coefficient of ACA being - 0.068421 suggest that if ACA should increase by 1 unit, FRQ will decrease by 0.068421 units. The fixed effect result shows that there is a negative and statistically insignificant relationship between audit committee attendance at meetings and financial reporting quality of deposit money banks in Nigeria. Therefore the null hypothesis is accepted. Though the negative relationship between audit committee attendance at meetings and financial reporting quality has conform to expectation, it cannot be totally overruled that audit committee attendance at meetings has no correlation with the control variables of firm age and size.

Audit Committee Size (ACS) with a coefficient of 0.233860 suggest that if (ACS) should increase by 1 unit, FRQ will increase by 0.233860 units. Hence, there is a positive relationship between audit committee size and financial reporting quality of deposit money banks in Nigeria. Thus, this provides evidence to reject the null hypothesis. This is consistent with the work of DeZorth et al (2002) who found that an audit committee should have an adequate number of members in order to achieve a fundamental result from its discussions and to also consider emerging issues. When the committee size is large, it brings about various ideas and perspective among members which will encourage shared knowledge thereby ensuring effective monitoring of financial reporting. However the findings are inconsistent with the works of Davidson, Steward \& Kent (2005) and Saleh, Iskandar \& Rahmat (2007) who found no positive relationship between audit committee size and financial reporting quality. They argued that audit committee size is not a dominant proxy for audit committee effectiveness.

The coefficient of firm size (FRS) and firm Age (FRA) being (0.072824) and 0.010077 respectively suggest that a unit increase in firm size (FRS) and firm age will increase FRQ by (0.072824) and 0.010077 units respectively. The finding of this study suggests that firm age and firm size positively impact financial reporting quality, however, not statistically significant because there probability is greater than $5 \%$. The positive and significant influence as indicated by the pooled OLS and the Fixed effect result respectively implies that older and larger firms who must have built reputation over the years tends to provide better and more qualitative financial report in order to maintain the confidence of their users.

\section{Conclusion and Recommendation}

This paper explores how audit committee attributes (Size, Expertise, Frequency of meetings, Independence and Attendance) influences the financial reporting quality of deposit money banks in Nigeria. Following the result of the data analysed, the following specific conclusions was made: audit committee attribute of size has positive and statistically insignificant influence on financial reporting quality of deposit money banks in Nigeria; audit committee attribute of expertise has positive and statistically significant effect on financial reporting quality of deposit money banks in Nigeria; audit committee attribute of frequency of meetings has positive and statistically insignificant influence on financial reporting quality of deposit money banks in Nigeria; audit committee attribute of attendance and independence has negative and insignificant influence on financial reporting quality of Nigerian banks. More so, firm age and size has positive impact on financial reporting quality of deposit money banks in 
Nigeria.

Hence, in order to enhance financial reporting quality in Nigerian Deposit money banks via audit committee, regulatory bodies like the Financial Reporting Council of Nigeria and the Central Bank of Nigeria being the apex bank that regulate the activities of corporations including deposit money banks in Nigeria should make it a policy that appointment of members of audit committee be made strictly of non-executive directors who are expert in accounting and belong to a professional accounting body. Moreover the provision for non-executive directors is also in compliance with the provision made by the code of corporate governance. The CAMA 2004 as amended recommends among others that audit committee meet at least three times a year however, this recommendation should be amended to increasing the number of meetings to be more frequently in order to ensure that financial reports are free from material mis-statement thereby ensuring a qualitative and reliable financial report.

\section{REFERENCES}

Abbott, L.J., Parker, S. \& Peters, G.F., (2004). “Audit committee characteristics and restatements". Journal of Practice and Theory of Auditing, 23, 69-87.

Al-Baidhani, A. M.(2014). The role of audit committee in corporate governance: Descriptive study. Putra Business School University Putra Malaysia. Retrieved from http://ssm.com/abstract=2487167.

Andrie, R.C., \& Melinda,T.F. (2014). The role of audit committee in corporate governance- case Study for a sample of companies listed on Bucharas Stock Exchange and the London stock Exchange. Procedia Economics and Finance 15 (1033-1041). Retrieved from www.sciencedirect.com.

Barako, D. G., Hancork, P., \& Izan, H. I. (2006). Factors influencing voluntary corporate disclosure by Kenyan companies. Corporate Governance: An international Review, 14(2), 107- 125.

Belkauni-Riahi, A. (2000). Level of Multinationalism, Growth opportunities and size as determinants of analysts ratings of corporate disclosure. American Business Review, 19(2), 115-220

Beest, F., Braam, G., \& Boelens, S., (2009) 'Quality of financial reporting: Measuring qualitative Characteristics'” Nice Working Paper 09-108, April.

Blue Ribbon Committee on Improving the Effectiveness of Corporate Audit Committees. (1999). Report and recommendations of the Blue Ribbon Committee on improving the Effectiveness of Corporate Audit Committee New York, NY: New York Stock Exchange and the National Association of Securities Dealers.

Cohen, J. R., Krisnamorthy, G., \& Wright, A., (2008). Form versus Substance: The implication for Auditing Practise and Research of Alternative Perspective on Corporate Governance. AUDITING; Journal of practice and Theory, 27, 181-198.

Davidson, R., Steward. J.G., \& Kent, P., (2005). Internal Governance Structure and Earnings Management. Accounting and Finance, 45(2) 241-267.

Dezoort, F.T. \& Salteno, S.E. (2001). The effect of corporate governance experience and Financial reporting and audit knowledge on audit committee member's judgements. Auditing: A journal of practise and theory 20 (2) $31-47$

Erena, O. T \& Tehulu, T. A. (2012). The impact of corporate governance mechanisms on earnings management: International journal of Research in Commerce, Economics and Management, 2 (8), 31-45.

FASB (1999). International Standard Setting: A Vision for the future. Norwalk.

Ferdy, V. B., Geert. B., \& Suzanne, B. (2009) Quality of Financial Reporting: Measuring Qualitative Characteristics. Nijmegen Center for Economics (NICE) Institute for Management Research Radboud University Nijgemen, Netherlands. Retrieved on 2/4/2018 from http://www.run//nice/working papers.

Gary, C. B., Gilles. H., \& Rodrigo, S.V. (2009). How Dos Financial Reporting Quality Relate to Investment Efficiency. Retrieved on 2/4/2018 from http://ssm.com/abstract $=1146536$

Hillman, A. J., Cannella, A. A., \& Paetzold, R. L.(2000). The Resource Dependent Role of Corporate Directors: Strategic adaptation of Board Composition in Response to Environmental Change. Journal of management studies 37, 235-256

IASB (2008). Exposure draft on an improved conceptual framework for financial reporting: The objective of financial reporting qualitative characteristics of decision-useful financial reporting information. London

ICANZ (1993).Statement of Concept for General purpose Financial Reporting. New Zealand Society of Accountants.

Klein, A. (2002). Audit committee, board of directors characteristics and earnings management. Journal of Accounting and Economics, 33 (3), 375-400.

Menon, K. \& Williams, J. D. (1996). 'The use of audit committee for monitoring'. Journal of Accounting and Public Policy, 13, 121-139

McMullen, D. A \& Raghunanda, K. (1996). Enhancing audit committee effectiveness. Journal of Accountancy, $182(2), 79$

Moau, Y.T. (2013). Measuring the relationship between audit committee characteristics and Earnings management. Evidence from New Zealand listed companies. Dissertation Submitted at Lincoln University New Zealand. 
Joseph,V.C., Carl,W. H., April, K., \& Terry, L.N (2006). Audit committee financial expertise, Competing corporate governance mechanism and earnings management

Ormin, K. \& Tuta, B. I. (2014). Audit Committee Attributes and Financial Reporting Quality Of Listed Nigerian Deposit Money Banks: A Qualitative Approach. Adsu Journal of Accounting Research 3(1\&2).

Robinson, D. R. \& Owens-Jackson, L. A. (2009). Audit Committee Characteristics and Auditor Changes. Academy of Accounting and Financial Studies Journal, 13, 117-133.

Saleh, N. M., Iskandar, T. G., \& Rahmat, M. M.(2007). Audit Committee Characteristics and

Earnings Management: Evidence from Malaysia. Asian Review of Accounting 15(2) 147- 163.

Samuel, A., Mudzamir, A. \& Mohammed, A. (2017). Audit Committee Effectiveness of Financial Reporting Quality in Listed Companies in Nigeria Stock Exchange. International journal of Academic Research in Business and Social Sciences Vol.7 No.6

Sarbanes-Oxley Act of (2002), (SOX ) Public law 107 th congress, $2^{\text {nd }}$ Session, July 24. Retrieved From www.Congress.gov. [Accessed 28/3/2018].

SEC (2003). Disclosure Requiered by Sections 406 and 407 of the Sarbanes Oxley Act of 2002, Release NO.338177 ; 34-47235, January 23, 2003. Available on SEC. gov.

Shawn, G. (2003). http://study.com/academy/lesson/what is financial reporting.

Siriyana, K. H. \& Norah, A. (2017). Fianancial Reportiig Quality: A Literature Review. International journal of Business Management and Commerce Vol.2 No. 2

Treadway Commission (1987). Report of the National Commission on Fraudulent Financial Reporting Octorber 1987 http://www.coso.org/Publications/NCFFR.pdf. [ Accessed 11/5/2018]

Warren, C. S. \& Reeve, T. M. (2004). Financial Accounting. Thomson

Xiaosong, Z. (2010). A Comparative Study of Financial Reporting Quality. $6^{\text {th }}$ International Scientific Conference May 13-14, 2010, Vilnius, Lilthuania Business and Management China.

Yuanto, K., Kwong, S. L., Themin, S., \& Jiwei, W. (2000). Audit Committee and Financial Reporting Quality in Singapore. Journal of Business Ethics school of Accountancy Research Paper Series Vol.3, No.2.

Yusof, M. A. M. (2010). Does audit committee constraint discretionary accruals in MESDAQ Listed companies? International journal of business and social science, 1 (3), 123-136.

\section{APPENDIX 1}

Dependent Variable: LOG(FRQ)

Method: Panel Least Squares

Date: 05/10/18 Time: 11:25

Sample: 20082017

Periods included: 10

Cross-sections included: 10

Total panel (unbalanced) observations: 52

\begin{tabular}{lllll}
\hline \hline Variable & Coefficient & Std. Error & t-Statistic & Prob. \\
\hline \hline C & -0.377109 & 0.238990 & -1.577929 & 0.1217 \\
LOG(ACE) & 0.306425 & 0.046357 & 6.610089 & 0.0000 \\
LOG(ACA) & 0.077459 & 0.122829 & 0.630630 & 0.5315 \\
LOG(MF) & -0.095909 & 0.206372 & -0.464737 & 0.6444 \\
LOG(ACI) & -0.134491 & 0.075439 & -1.782784 & 0.0815 \\
LOG(ACS) & -0.362561 & 0.466006 & -0.778018 & 0.4407 \\
LOG(FRS) & 0.008683 & 0.085149 & 0.101977 & 0.9192 \\
LOG(FRA) & 0.336900 & 0.086549 & 3.892588 & 0.0003 \\
\hline \hline R-squared & 0.628964 & Mean dependent var & -0.237565 \\
Adjusted R-squared & 0.569935 & S.D. dependent var & 0.151766 \\
S.E. of regression & 0.099527 & Akaike info criterion & -1.636141 \\
Sum squared resid & 0.435846 & Schwarz criterion & -1.335950 \\
Log likelihood & 50.53966 & Hannan-Quinn criter. & -1.521055 \\
F-statistic & 10.65527 & Durbin-Watson stat & 1.491869 \\
Prob(F-statistic) & 0.000000 & & & \\
\hline \hline
\end{tabular}




\section{APPENDIX II}

Dependent Variable: LOG(FRQ)

Method: Panel EGLS (Cross-section random effects)

Date: 05/10/18 Time: 11:27

Sample: 20082017

Periods included: 10

Cross-sections included: 10

Total panel (unbalanced) observations: 52

Swamy and Arora estimator of component variances

\begin{tabular}{lllll}
\hline \hline Variable & Coefficient & Std. Error & t-Statistic & Prob. \\
\hline \hline C & -0.309899 & 0.164362 & -1.885471 & 0.0660 \\
LOG(ACE) & 0.317803 & 0.030297 & 10.48969 & 0.0000 \\
LOG(ACA) & -0.026651 & 0.079641 & -0.334637 & 0.7395 \\
LOG(MF) & -0.012814 & 0.137068 & -0.093490 & 0.9259 \\
LOG(ACI) & -0.105623 & 0.054217 & -1.948156 & 0.0578 \\
LOG(ACS) & 0.091620 & 0.298193 & 0.307250 & 0.7601 \\
LOG(FRS) & 0.059831 & 0.058816 & 1.017259 & 0.3146 \\
LOG(FRA) & 0.236388 & 0.099176 & 2.383516 & 0.0215 \\
\hline \hline & Effects Specification & & S.D. \\
\hline \hline
\end{tabular}

Weighted Statistics

\begin{tabular}{llll}
\hline \hline R-squared & 0.683638 & Mean dependent var & -0.116513 \\
Adjusted R-squared & 0.633307 & S.D. dependent var & 0.119013 \\
S.E. of regression & 0.071038 & Sum squared resid & 0.222040 \\
F-statistic & 13.58301 & Durbin-Watson stat & 1.916714 \\
Prob(F-statistic) & 0.000000 & & \\
\hline \hline & Unweighted Statistics & \\
\hline \hline R-squared & 0.594607 & Mean dependent var & -0.237565 \\
Sum squared resid & 0.476204 & Durbin-Watson stat & 1.203231 \\
\hline \hline
\end{tabular}




\section{APPENDIX III}

Dependent Variable: LOG(FRQ)

Method: Panel Least Squares

Date: 05/10/18 Time: 11:32

Sample: 20082017

Periods included: 10

Cross-sections included: 10

Total panel (unbalanced) observations: 52

\begin{tabular}{lllll}
\hline \hline Variable & Coefficient & Std. Error & t-Statistic & Prob. \\
\hline \hline C & -0.165426 & 0.194117 & -0.852196 & 0.3999 \\
LOG(ACA) & -0.068421 & 0.084229 & -0.812325 & 0.4221 \\
LOG(ACE) & 0.321504 & 0.031796 & 10.11144 & 0.0000 \\
LOG(MF) & 0.016573 & 0.144832 & 0.114428 & 0.9096 \\
LOG(ACI) & -0.074545 & 0.058346 & -1.277629 & 0.2098 \\
LOG(ACS) & 0.233860 & 0.301858 & 0.774737 & 0.4437 \\
LOG(FRS) & 0.072824 & 0.062827 & 1.159127 & 0.2543 \\
LOG(FRA) & 0.010077 & 0.250725 & 0.040192 & 0.9682 \\
\hline \hline
\end{tabular}

Effects Specification

Cross-section fixed (dummy variables)

\begin{tabular}{llll}
\hline \hline R-squared & 0.887301 & Mean dependent var & -0.237565 \\
Adjusted R-squared & 0.835782 & S.D. dependent var & 0.151766 \\
S.E. of regression & 0.061501 & Akaike info criterion & -2.481569 \\
Sum squared resid & 0.132384 & Schwarz criterion & -1.843663 \\
Log likelihood & 81.52080 & Hannan-Quinn criter. & -2.237011 \\
F-statistic & 17.22267 & Durbin-Watson stat & 2.190024 \\
Prob(F-statistic) & 0.000000 & & \\
\hline \hline
\end{tabular}

\section{APPENDIX IV}

Correlated Random Effects - Hausman Test

Equation: Untitled

Test cross-section random effects

\begin{tabular}{llll}
\hline \hline Test Summary & $\begin{array}{l}\text { Chi-Sq. } \\
\text { Statistic }\end{array}$ & Chi-Sq. d.f. & Prob. \\
\hline \hline Cross-section random & 21.872818 & 7 & 0.0027 \\
\hline \hline
\end{tabular}

Cross-section random effects test comparisons:

\begin{tabular}{lllll} 
Variable & Fixed & Random & Var(Diff.) & Prob. \\
\hline \hline LOG(ACA) & -0.068421 & -0.026651 & 0.000752 & 0.1277 \\
LOG(ACE) & 0.321504 & 0.317803 & 0.000093 & 0.7013 \\
LOG(ACI) & -0.074545 & -0.105623 & 0.000465 & 0.1494 \\
LOG(ACS) & 0.233860 & 0.091620 & 0.002199 & 0.0024 \\
LOG(MF) & 0.016573 & -0.012814 & 0.002189 & 0.5299 \\
LOG(FRS) & 0.072824 & 0.059831 & 0.000488 & 0.5564 \\
LOG(FRA) & 0.010077 & 0.236388 & 0.053027 & 0.3257 \\
\hline \hline
\end{tabular}


Cross-section random effects test equation:

Dependent Variable: LOG(FRQ)

Method: Panel Least Squares

Date: 05/10/18 Time: 11:34

Sample: 20082017

Periods included: 10

Cross-sections included: 10

Total panel (unbalanced) observations: 52

\begin{tabular}{lllll}
\hline \hline Variable & Coefficient & Std. Error & t-Statistic & Prob. \\
\hline \hline C & -0.165426 & 0.194117 & -0.852196 & 0.3999 \\
LOG(ACA) & -0.068421 & 0.084229 & -0.812325 & 0.4221 \\
LOG(ACE) & 0.321504 & 0.031796 & 10.11144 & 0.0000 \\
LOG(ACI) & -0.074545 & 0.058346 & -1.277629 & 0.2098 \\
LOG(ACS) & 0.233860 & 0.301858 & 0.774737 & 0.4437 \\
LOG(MF) & 0.016573 & 0.144832 & 0.114428 & 0.9096 \\
LOG(FRS) & 0.072824 & 0.062827 & 1.159127 & 0.2543 \\
LOG(FRA) & 0.010077 & 0.250725 & 0.040192 & 0.9682 \\
\hline \hline
\end{tabular}

Effects Specification

Cross-section fixed (dummy variables)

\begin{tabular}{llll}
\hline \hline R-squared & 0.887301 & Mean dependent var & -0.237565 \\
Adjusted R-squared & 0.835782 & S.D. dependent var & 0.151766 \\
S.E. of regression & 0.061501 & Akaike info criterion & -2.481569 \\
Sum squared resid & 0.132384 & Schwarz criterion & -1.843663 \\
Log likelihood & 81.52080 & Hannan-Quinn criter. & -2.237011 \\
F-statistic & 17.22267 & Durbin-Watson stat & 2.190024 \\
Prob(F-statistic) & 0.000000 & & \\
\hline
\end{tabular}

